\title{
Updates on Treatment Approaches for Cutaneous Field Cancerization
}

\author{
Alisen Huang ${ }^{1} \cdot$ Julie K. Nguyen ${ }^{1} \cdot$ Evan Austin $^{1} \cdot$ Andrew Mamalis $^{1} \cdot$ Jared Jagdeo $^{1}$
}

Published online: 19 July 2019

(C) The Author(s) 2019

\begin{abstract}
Purpose of Review Field cancerization describes the phenomenon that multiple heterogenous mutations may arise in an area exposed to chronic carcinogenic stimuli. Advances in the understanding of cutaneous field cancerization have led to novel therapeutic approaches to the management of actinic keratoses (AKs). Herein, we review the literature on the pathophysiology and emerging research of field cancerization in dermatology.

Recent Findings The classification systems for grading AK lesions are being refined with investigations focusing on their clinical utility. There is a growing shift toward field-directed treatment for AKs as the importance of field cancerization becomes clearer. Current field-directed therapies are being optimized and novel therapeutic modalities are being studied.

Summary Field cancerization underlies the transformation of photodamaged skin into AKs and potentially cutaneous squamous cell carcinoma (cSCC). Clinically meaningful classification systems for AKs are needed to better inform decisions regarding treatment. As we learn more about the role of field characterization in photodamage, AKs, and cSCCs, therapeutic strategies are becoming more field-directed rather than lesion-directed.
\end{abstract}

Keywords Field cancerization · Actinic keratosis · Cutaneous squamous cell carcinoma $\cdot$ Photodamage $\cdot$ Photodynamic therapy

\section{Introduction}

\section{Field Cancerization Concept}

Field cancerization describes the phenomenon that multiple heterogenous mutations may arise in an area exposed to chronic carcinogenic stimuli [1••]. As one or more cells undergo irreversible genetic changes that persist over multiple cycles of cell division, a dysplastic field emerges [1••]. Invasive properties are not evident initially, but as somatic mutations accumulate from carcinogen exposure, subclonal proliferations may eventually induce carcinoma $[1 \bullet \bullet, 2]$. The term "field cancerization" was first coined and described in a landmark study by Slaughter et al. in 1953 in reference to

Julie K. Nguyen and Evan Austin contributed equally to this work.

This article is part of the Topical Collection on Skin Cancer

Jared Jagdeo

jrjagdeo@gmail.com

1 Department of Dermatology, Downstate Medical Center, State University of New York, 450 Clarkson Ave, Brooklyn, NY 11203, USA oropharyngeal squamous cell carcinoma (SCC) [3]. Areas adjacent to the tumor appeared grossly normal but histopathologic examination demonstrated dysplastic changes and foci of oropharyngeal SCC in situ [3]. The findings of discrete primary tumors and islands of dysplastic epithelium suggested that the tumors had simultaneously developed independent of each other, rather than from the clonal proliferation of a single mutant cell [2].

The concept of field cancerization is especially relevant in dermatology, as it describes how actinic keratosis (AK) lesions develop and subsequently transform into cutaneous SCC (cSCC), the second most common malignancy in the US [4]. A committee of European dermatologists defined field cancerization as the anatomical area including or adjacent to AKs with visibly photodamaged skin, characterized by pigmentary changes, rough texture, atrophy, or telangiectasia [5].

Field cancerization has significant therapeutic implications and clinical consequences in dermatology. AKs are typically viewed as precancerous; however, treatment of individual lesions often does not address mutations in nearby cells that may be transforming into cancer [2]. AKs are one of the most prevalent diagnoses in dermatology and are expected to increase with the aging population and increased exposure to sunlight [6]. In 2015, over 35 million cases of AKs were 
treated in the Medicare Part B fee-for-service population, up from 29.7 million in 2007, highlighting the treatment burden of this condition [7]. AKs have been estimated to cost the US healthcare system $\$ 920$ million annually [8]. There is up to $0.075 \%$ risk per lesion-year of $\mathrm{AK}$ transformation to $\mathrm{cSCC}$, increasing to $2.57 \%$ at 4 years $[9,10]$.

Currently, there is no reliable method to discern AKs that will transform into cSCCs from those that will either remain benign or resolve without treatment, complicating the treatment algorithm of AKs. Various approaches are being investigated for this unanswered question including imaging techniques and genotyping $[5,11]$. The Department of Veterans Affairs Topical Tretinoin Chemoprevention (VATTC) trial is a 5-year multicenter clinical trial that followed individual $\mathrm{AK}$ lesions. By 1 year, $55 \%$ of AKs had regressed, and at 5 years, $70 \%$ were not present [10]. Of note, some AKs not present at the 1 year follow-up were present at later follow-up visits, which is consistent with the reported regression and recurrence of AKs [10]. Of the primary cSCCs that were diagnosed, $65 \%$ of those arose from lesions that were initially diagnosed as AKs [10]. Interestingly, 36\% of basal cell carcinomas (BCCs) were diagnosed from lesions that were previously diagnosed as AKs, indicating that either BCCs and cSCCs may share a common underlying pathogenesis or the initial AK diagnosis was incorrect [10]. Another study estimated that approximately $10 \%$ of AKs will undergo malignant transformation into cSCC with the average time for conversion being 24.6 months (range 2 to 65 months) [12]. Without intervention, resulting cSCC may subsequently lead to significant healthcare expenditure, patient morbidity, and patient mortality. In 2013, it was estimated that each year in the US, cSCC causes between 4000 and 9000 deaths and bears a $\$ 4$ billion economic burden [6]. While the risk of a single AK transformation to cancer is overall low, patients typically have many AKs or at least multiple fields of precancerous, photodamaged skin.

Understanding field cancerization is important for elucidating the malignant transformation process from normal skin to cSCC. Determining the risk of cSCC development from a single lesion as well as risk for a field may improve patient outcomes by identifying those patients who would benefit most from earlier treatment [2]. Herein, we discuss the emerging research of field cancerization in dermatology, with emphasis on the most recent research literature on the pathogenesis, classification, and treatments of AKs.

\section{Pathogenesis}

Photodamage is caused by chronic ultraviolent (UV) radiation exposure from sunlight and is associated with detrimental consequences to the skin, such as atrophy and increased risk of cancer [13]. UVA irradiation $(320-400 \mathrm{~nm})$ is associated with indirect damage to DNA by oxidative injury via reactive oxygen species (ROS) [14]. UVB irradiation (290-320 nm) causes direct damage to DNA by inducing structural rearrangements of nucleotides, such as thymidine dimerization, leading to physical distortions in the DNA strands [15]. The collective DNA damage and mutations over time interfere with replication and transcription, resulting in cutaneous cancerization of the field and clinically manifesting as varying degrees of photodamaged skin [16]. Field cancerization of the skin begins when UV radiation induces a sporadic somatic mutation in epidermal keratinocytes (Fig. 1) [1••]. With chronic exposure to UV radiation, clonal expansion occurs and mutations accumulate, leading to AKs on sun-exposed skin [1••]. As UV radiation non-selectively damages DNA, AKs may have varying mutations and may be at different stages of development [5]. The transformation of AKs to cSCC is thought to occur in a stepwise fashion with progressive development of epidermal neoplasia, which has been classified clinically by Olsen et al. and histologically by Rowert-Huber et al. [17, 18]. For clinical research purposes, AKs are graded based on thickness and the degree of hyperkeratosis: AK 1 is better palpated than visualized, AK 2 is visible, and AK 3 is hyperkeratotic [17]. Histologically, AKs are graded based on the extent of epidermal atypical keratinocytes: AKI is limited to epidermal basal layer, AKII extends to the lower two thirds of the epidermis, and AKIII involves the full epidermal thickness [18]. Histologically graded AKI was recently found to be the most common precursor to $\mathrm{cSCC}$ as progression occurs through direct invasion from proliferating atypical keratinocytes, such that any grade of AKs may be invasive [19••].

In photodamaged skin, AKs, and cSCCs, evidence of the TP53 tumor suppressor protein was observed in keratinocytes and has been recorded in 69 to over $90 \%$ of invasive cSCC $[20,21]$. Other implicated mutations in field-cancerized islands include the oncogenes c-myc, Ras, H-ras, c-jun, WNT, and KNSTRN and the tumor suppressors, p16INK4, NF-kB, Notch1, Notch2, Hes1, and Erdr1 [2, 16, 20, 22, 23]. Some studies have genotyped AKs and cSCC to identify potential key biomarkers which may be useful for diagnosis, prevention, or treatment [11, 24, 25].

Since AKs and cSCC share many genetic features, AKs are used as a risk marker for $\mathrm{cSCC}$; however, there is emerging evidence that AKs may also herald other types of skin cancer [1••]. One study found evidence of histologically present AKs in $57 \%(35 / 61)$ of cSCC specimens, 33\% (21/64) of basal cell carcinoma specimens, and $25 \%(6 / 24)$ of malignant melanoma specimens $[1 \bullet \bullet$. The extent of field damage may be even larger than reported as only $0.1 \mathrm{~mm}$ of the distal lateral margin was assessed for discontiguous foci of dysplasia [1••]. The relationship between $\mathrm{AKs}$ and other cutaneous malignancies is unclear, but these findings are significant as they suggest that any cutaneous malignancy may be surrounded by an expanding pre-neoplastic field $[1 \bullet]$. Another study 


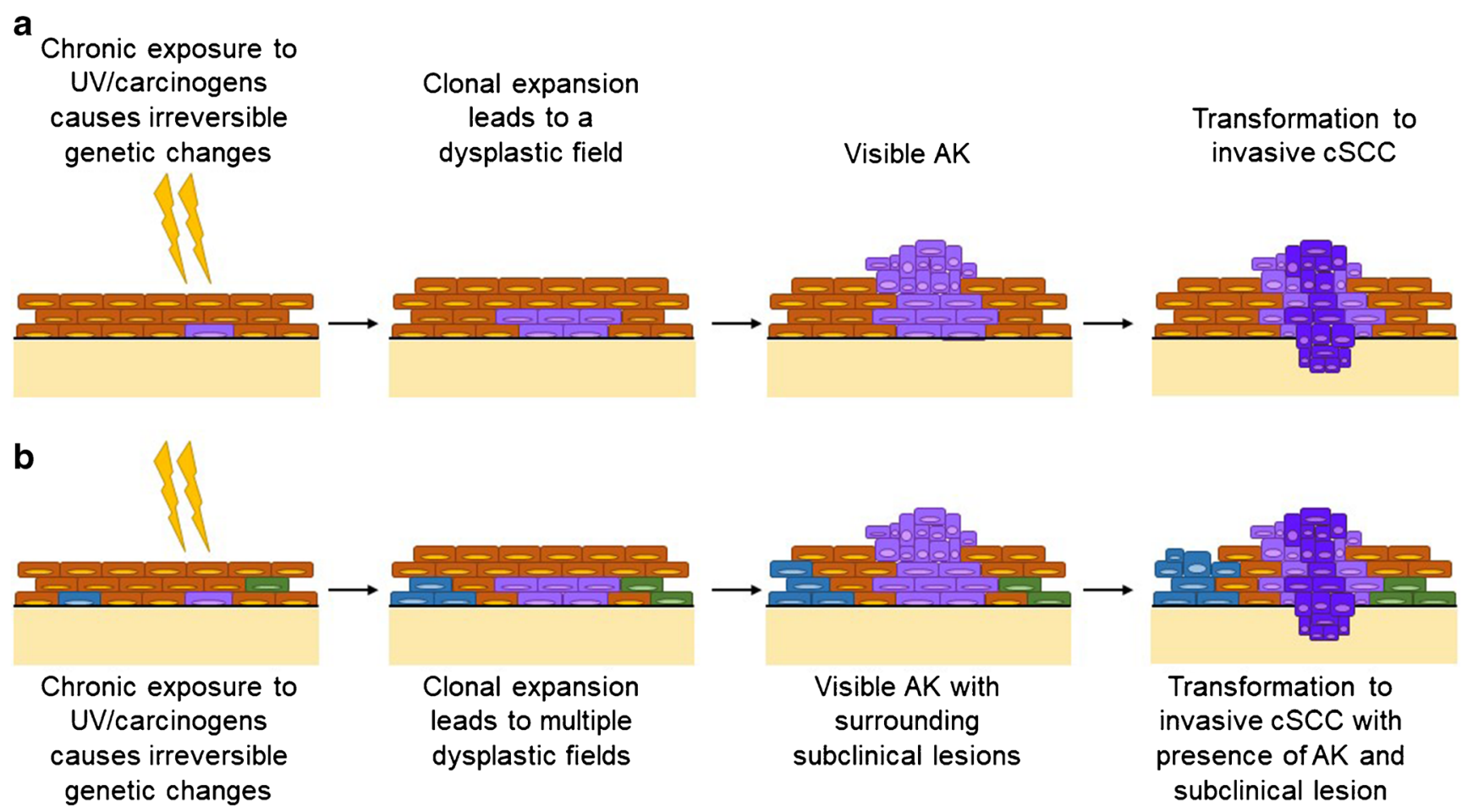

Fig. 1 Field cancerization theory. a Previous theory of cSCC formation. b Current field cancerization theory. UV ultraviolet, cSCC cutaneous squamous cell carcinoma, AK actinic keratosis

demonstrated a $42 \%$ risk of developing subsequent cSCC within 5 years of the original diagnosis and a $72 \%$ increase in risk if the patient had two or more cSCCs at the initial time of diagnosis [2,26]. Thus, a patient with a known diagnosis of $\mathrm{cSCC}$ is at increased risk of developing additional cSCCs.

\section{AK Classification}

The wide variety of clinical and histological presentations of AKs presents a challenge to developing a uniform grading system that predicts whether a lesion will regress or progress. Grading of AKs based on thickness was found to be inconsistent among experts [5, 17]. Grading based purely on histology is not specific enough as histological findings may overlap with other keratinocyte diseases such as Bowen's disease and seborrheic keratosis [18]. Additionally, there is no evidence to support that the stepwise progression from AKI to AKIII is necessary for the transformation of atypical keratinocytes into cSCC [27]. Other classification schemes based on lesion size, number of lesions, and histological findings are focused on individual lesions, an approach that does not consider the process of field cancerization and spontaneous mutations [28].
In 2017, two scales were developed and validated to measure AKs in the context of field cancerization, the Actinic Keratosis Area and Severity Index (AKASI) and the Actinic Keratosis Field Assessment Scale (AK-FAS) [29, 30]. The AKASI evaluates AK parameters including severity on the head, area of extent, and clinical features (i.e., distribution, erythema, and thickness) [29]. The AK-FAS is used to grade AK severity based on AK area (as opposed to number of lesions), hyperkeratosis severity, and sun damage severity [30]. These scales are not widely used in the clinical setting, possibly due to their recent introduction.

One of the major issues with grading is the heterogeneous nature of field cancerization, which leads to a variety of grades within a single lesion [31]. Two thirds (67\%) of AKs have more than one grade [31]. The diverse grading within a lesion also means that histopathological information from one biopsy may not be extrapolated to the entire field. One solution is to classify AKs based on their development; this requires a better understanding of the role of field cancerization in $\mathrm{AK}$ and cSCC development [27]. The predictive value of field disarray in lesion progression also requires further investigation as earlier identification of lesions with malignant potential may result in better patient outcomes and decrease the financial burden of this disease. 


\section{Management/Treatment}

The ideal management of field cancerization is through patient education on the importance of UV exposure avoidance (i.e., using high SPF sunscreen that protects against UVA and UVB rays) to minimize photodamage [2]. Recently, oral nicotinamide (vitamin B3) has been advocated for use as skin cancer chemoprevention due to its protective effects against UV-induced cutaneous damage, reducing the rate of new AKs in high-risk patients [32]. The therapeutic mechanisms of nicotinamide involve enhancement of DNA repair via blockade of UV-induced ATP depletion [32]. This chemopreventative method may supplement behavioral modifications in patients at higher risk of developing AKs.

If the patient has already developed AKs, then treatment is usually offered in routine clinical practice. As there is no reliable way to determine which AKs will become cSCCs, the prevailing recommendation by expert consensus is to treat all lesions [2]. Treatment for AKs may be lesion-directed or fielddirected. Lesion-directed therapies are adequate for welldefined lesions and may be useful when complete clearance is not achieved by other methods [33]. Recently, there has been a shift toward field-directed therapy using topical agents, photodynamic therapy (PDT), chemical peels, laser resurfacing, etc. [34, 35•, 36]. Since field cancerization causes multifocal areas of dysplasia and precancerous changes, a single diagnosis of cSCC signifies increased risk of subsequent cSCC and therefore may require long-term follow-up [2]. Subsequent cSCC may be recurrence of the primary cSCC or may arise as a new primary cancer due to the heterogeneity of field cancerization (Fig. 2) [2]. Currently available fielddirected therapies are being optimized and new field-directed topical agents and laser therapies are discussed below. In

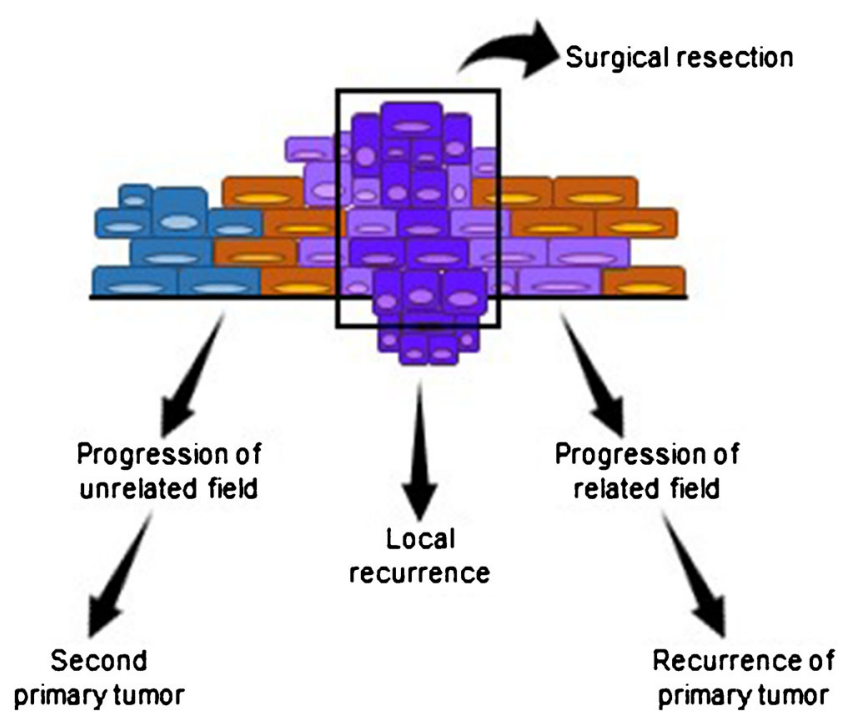

Fig. 2 Field cancerization and local recurrences of tumors addition, Table 1 describes clinical trials currently being conducted in the US for AK treatment.

\section{Currently Available}

\section{5-Fluorouracil and Imiquimod}

5-fluorouracil (5-FU) and imiquimod are two topical agents that are well-established and commonly used for field-directed therapies for AKs [37]. 5-FU is available in cream formulation with $0.5 \%, 1 \%$, and $5 \%$ strengths. The $5 \%$ cream is applied twice daily for 2 to 4 weeks whereas $0.5 \%$ and $1 \%$ creams are applied daily for 3 to 4 weeks [38]. Imiquimod is available as $3.75 \%$ and $5 \%$ creams. The $3.75 \%$ cream is applied once daily for $8 \mathrm{~h}$ for two 2-week treatment cycles separated by a 2-week no-treatment period whereas the $5 \%$ cream is applied two times per week for $8 \mathrm{~h}$ for 16 weeks $[39,40]$.

More recent studies combine AK therapies, use different concentrations, or report rare adverse events [41-46]. Combination therapy studies include 5\% 5-FU and $0.005 \%$ calcipotriol, which was found to reduce the number of AK lesions by $87.8 \%$ compared with $26.3 \%$ for $5 \% 5$-FU and white petrolatum in mice [45]. This effect was thought to be related to an activation of $\mathrm{CD}^{+} \mathrm{T}$ cell-mediated immunity [45]. Different concentrations of imiquimod, $2.5 \%$ and $3.75 \%$, were studied in a meta-analysis of four phase III clinical trials [46]. These doses are lower than the typical 5\% imiquimod for use as short-term cycle therapy or an expanded treatment area [46]. The two concentrations showed dose-related effects on Combined Investigator's Global Integrated Photodamage score and both performed significantly better than the control cream [46]. While 5-FU and imiquimod are considered safe, there have been recent case reports of rare adverse reactions. One report described fever, fatigue, mucositis, dehydration, and significant weight loss, thought to be related to a dihydropyrimidine dehydrogenase deficiency, leading to decreased drug clearance and systemic 5-FU accumulation after $0.5 \%$ topical 5-FU [42]. Another case report described a patient with blistering, peeling, and painful erythema after overapplying the topical 5\% 5-FU she was prescribed [44].

\section{Photodynamic Therapy}

PDT consists of topical application of a photosensitizing agent that is activated by light. In the case of aminolevulinic acid (ALA), one of the more commonly used photosensitizing agents in the US, precursors of the heme pathway are converted to protoporphyrin IX (PpIX) in the skin [47]. PpIX generates ROS when exposed to light irradiation, typically red or blue light, leading to cell death and an inflammatory response [47]. Red light PDT has been a staple in European PDT and is being reintroduced to the US market. Red light penetrates deeper than other wavelengths of visible light and 
Table 1 Ongoing clinical trials for AK investigation in the USA. NA not available

\begin{tabular}{|c|c|c|c|c|c|}
\hline & Study title (identifier) & Phase & Interventions & Study design & $\begin{array}{l}\text { Primary outcome } \\
\text { (time frame) }\end{array}$ \\
\hline \multirow[t]{5}{*}{ PDT } & $\begin{array}{l}\text { Daylight Photodynamic Therapy for Actinic } \\
\text { Keratosis (NCT03322293) }\end{array}$ & 1 & $\begin{array}{l}\text { Drug: ALA Topical } 20 \% \\
\text { Topical Solution } \\
\text { Device: BLU-U blue light } \\
\text { phototherapy illuminator }\end{array}$ & $\begin{array}{l}\text { Randomized } \\
\text { Single-blind }\end{array}$ & $\begin{array}{l}\text { Reduction in } \\
\text { treatment } \\
\text { symptoms } \\
\text { (12 weeks) }\end{array}$ \\
\hline & $\begin{array}{l}\text { Protocols for Painless Photodynamic Therapy } \\
\text { (PDT) of Actinic Keratoses } \\
\text { (NCT02124733) }\end{array}$ & 3 & $\begin{array}{l}\text { Procedure: ALA-PDT with } \\
\text { altered incubation time ( } 0 \text { vs } \\
1 \mathrm{~h})\end{array}$ & $\begin{array}{l}\text { Randomized } \\
\text { Single-blind }\end{array}$ & $\begin{array}{l}\text { AK clearance } \\
(3 \text { months })\end{array}$ \\
\hline & $\begin{array}{l}\text { Photodynamic Therapy Incubation Times for } \\
\text { Actinic Keratosis } \\
\text { (NCT03066843) }\end{array}$ & NA & $\begin{array}{l}\text { Drug: ALA } \\
\text { Device: blue light therapy with } \\
\text { altered incubation time ( } 0 \mathrm{vs} \\
1 \mathrm{~h})\end{array}$ & $\begin{array}{l}\text { Randomized } \\
\text { Single-blind }\end{array}$ & $\begin{array}{l}\text { Change in number of } \\
\text { AK lesions } \\
\text { (baseline and } \\
8 \text { weeks) }\end{array}$ \\
\hline & $\begin{array}{l}\text { DUSA: Cyclic PDT for the Prevention of AK \& } \\
\text { NMSC in Solid Organ Transplant Recipients } \\
\text { (NCT03110159) }\end{array}$ & 1,2 & $\begin{array}{l}\text { Drug: Levulan }{ }^{\circledR} \text { Kerastick }{ }^{\circledR} \\
\text { Drug: BLU-U blue light } \\
\text { photodynamic therapy }\end{array}$ & $\begin{array}{l}\text { Single-group } \\
\text { Open-label }\end{array}$ & $\begin{array}{l}\text { Primary prevention } \\
\text { of AKs and } \\
\text { NMSCs ( } 3 \text { years) } \\
\text { Time to occurrence } \\
\text { of AKs and } \\
\text { NMSCs ( } 3 \text { years) }\end{array}$ \\
\hline & $\begin{array}{l}\text { Biomarker Database Registry for Photodynamic } \\
\text { Therapy } \\
\text { (NCT03319251) }\end{array}$ & NA & PDT & NA & $\begin{array}{l}\text { AK clearance } \\
\text { ( } 3 \text { months }) \\
\text { Vitamin D levels } \\
\quad \text { (baseline) }\end{array}$ \\
\hline $\begin{array}{l}\text { VDA-1102: } \\
\text { anti-neoplastic } \\
\text { agent }\end{array}$ & $\begin{array}{l}\text { Study to Evaluate the Efficacy, Safety, and } \\
\text { Tolerability of Topical VDA-1102 Ointment in } \\
\text { Subjects With Actinic Keratosis (Phase2b) } \\
\text { (NCT03538951) }\end{array}$ & 2 & $\begin{array}{l}\text { Drug: } 10 \% \text { VDA-1102 } \\
\text { Drug: } 20 \% \text { VDA-1102 }\end{array}$ & $\begin{array}{l}\text { Open-label } \\
\text { Multi-center }\end{array}$ & $\begin{array}{l}\text { Complete clearance } \\
\text { rate }(16 \text { weeks }) \\
\text { Complete facial } \\
\text { clearance rate } \\
\text { (16 weeks) }\end{array}$ \\
\hline $\begin{array}{l}\text { SOR007: uncoated } \\
\text { nanoparticulate } \\
\text { paclitaxel } \\
\text { ointment }\end{array}$ & $\begin{array}{l}\text { Study of SOR007 Ointment for Actinic Keratosis } \\
\text { (NCT03083470) }\end{array}$ & 2 & $\begin{array}{l}\text { Drug: SOR007 (uncoated } \\
\text { nanoparticulate paclitaxel) } \\
\text { Ointment: } 0.15 \%, 1.0 \% \text {, } \\
2.0 \% \\
\text { Other: SOR007 ointment } \\
\text { vehicle }\end{array}$ & $\begin{array}{l}\text { Randomized } \\
\text { Double-blind }\end{array}$ & $\begin{array}{l}\text { Incidence of } \\
\text { treatment } \\
\text { emergent adverse } \\
\text { events ( } 28 \text { days) }\end{array}$ \\
\hline $\begin{array}{l}\text { SR-T100: } \\
\text { antiproliferative } \\
\text { agent }\end{array}$ & $\begin{array}{l}\text { Efficacy and Safety Phase II Study of SR-T100 to } \\
\text { Treat Actinic Keratosis } \\
\text { (NCT01516515) }\end{array}$ & 2 & $\begin{array}{l}\text { Drug: vehicle gel } \\
\text { Drug: SR-T100 with } 2.3 \% \text { of } \\
\text { SM }\end{array}$ & $\begin{array}{l}\text { Randomized } \\
\text { Double-blind }\end{array}$ & $\begin{array}{l}\text { Total clearance rate } \\
\quad(24 \text { weeks })\end{array}$ \\
\hline \multirow[t]{3}{*}{$\begin{array}{l}\text { KX2-391: Src } \\
\text { tyrosine kinase } \\
\text { inhibitor }\end{array}$} & $\begin{array}{l}\text { A Ph2a, Open-Label, Multicenter, Activity \& } \\
\text { Safety Study of KX2-391 Oint in Subj. w } \\
\text { Actinic Keratosis on the Face or Scalp } \\
\text { (NCT02838628) }\end{array}$ & 2 & Drug: KX2-391 & $\begin{array}{l}\text { Single-group } \\
\text { Open-label }\end{array}$ & $\begin{array}{l}\text { Complete response } \\
\text { rate (57 days) }\end{array}$ \\
\hline & $\begin{array}{l}\text { A Multi-Center Study to Evaluate the Efficacy } \\
\text { and Safety of KX2-391 Ointment 1\% on AK } \\
\text { on Face or Scalp (AK003) } \\
\text { (NCT03285477) }\end{array}$ & 3 & $\begin{array}{l}\text { Drug: KX2-391 ointment } 1 \% \\
\text { Drug: placebo }\end{array}$ & $\begin{array}{l}\text { Randomized } \\
\text { Double-blind } \\
\text { Multi-center }\end{array}$ & $\begin{array}{l}\text { Complete response } \\
\text { rate (57 days) }\end{array}$ \\
\hline & $\begin{array}{l}\text { A Multi-Center Study to Evaluate the Efficacy } \\
\text { and Safety of KX2-391 Ointment 1\% on AK } \\
\text { on Face or Scalp (AK004) } \\
\text { (NCT03285490) }\end{array}$ & 3 & $\begin{array}{l}\text { Drug: KX2-391 ointment } 1 \% \\
\text { Drug: placebo }\end{array}$ & $\begin{array}{l}\text { Randomized } \\
\text { Double-blind } \\
\text { Multi-center }\end{array}$ & $\begin{array}{l}\text { Complete response } \\
\text { rate (57 days) }\end{array}$ \\
\hline $5-\mathrm{FU}$ & $\begin{array}{l}\text { Evaluating Skin Appearance Following } \\
\text { 5-Flourouracil Cream for Treatment of Actinic } \\
\text { Keratosis and the Effects of Topical Agents } \\
\text { (NCT03279328) }\end{array}$ & 4 & $\begin{array}{l}\text { Drug: topical steroid ointment } \\
\text { Other: Vaseline } \\
\text { Drug: skin barrier moisturizer }\end{array}$ & $\begin{array}{l}\text { Randomized } \\
\text { Open-label }\end{array}$ & $\begin{array}{l}\text { Skin barrier } \\
\text { biophysical } \\
\text { properties }(2 \mathrm{~h})\end{array}$ \\
\hline CAP & $\begin{array}{l}\text { Using a Cold Atmospheric Plasma Device to } \\
\text { Treat Skin Disorders } \\
\text { (NCT02759900) }\end{array}$ & NA & $\begin{array}{l}\text { Device: non-thermal, } \\
\text { atmospheric plasma }\end{array}$ & $\begin{array}{l}\text { Single-group } \\
\text { Open-label }\end{array}$ & $\begin{array}{l}\text { Clinical } \\
\text { improvement } \\
\text { (1 month) }\end{array}$ \\
\hline Other & $\begin{array}{l}\text { Validation of SHADE a Mobile Technology for } \\
\text { Monitoring of Ultraviolet Exposure } \\
\text { (NCT03315286) }\end{array}$ & NA & $\begin{array}{l}\text { Device: SHADE Ultraviolet } \\
\text { Sensor } \\
\text { Behavioral: Standard of care } \\
\text { counseling }\end{array}$ & $\begin{array}{l}\text { Randomized } \\
\text { Double-blind }\end{array}$ & $\begin{array}{l}\text { Quantification of AK } \\
\text { (6 months) }\end{array}$ \\
\hline
\end{tabular}


has a higher fluence rate compared to blue light; this may cause more pain during light treatment $[48,49]$. PDT has minimal downtime although patients become more sensitive to light, which warrants precaution for sun exposure and medications that cause photosensitivity $[50,51]$. There is evidence that PDT may be able to correct dysplastic, photodamaged skin by altering cancer-associated gene expression [52••]. PDT has been reported to have desirable cosmetic effects when used to treat AKs through activation of processes involved in wound healing $[52 \bullet \bullet, 53]$. A phase III study using ALA and red light to treat an entire field found long-lasting skin rejuvenation in areas of asymptomatic photodamage in addition to being effective for the treatment of mild-tomoderate AK lesions [53].

PDT may not be as effective for AKs on the extremities due to the thermal dependence of endogenous PpIX generation [54••]. However, thermal PDT, which uses higher temperatures during incubation of the photosensitizer, results in better outcomes in field treatment of the extremities, shorter incubation times, and does not increase side effects [54••, 55-57, $58 \bullet \cdot$. Higher temperatures were achieved by wrapping the extremity tested with a heating pad to set "medium" which achieved maximal temperatures ranging from 37.2 to $43.4^{\circ} \mathrm{C}$ during incubation compared with a baseline of 29.6 to $33.6^{\circ} \mathrm{C}$ [54•*].

Since patients may experience discomfort during PDT, various strategies have been studied to mitigate this adverse effect, use of including of alternate light sources, pretreatments, and different photosensitizers. A variation to conventional PDT is to use daylight as an alternative light source to activate PpIX [59-61]. This method allows continuous and gradual activation of the photosensitizer with daylight rather than with red or blue light, resulting in decreased pain while still maintaining clearance rates similar to conventional PDT [59-65]. Metal halide white light may be an alternative to daylight PDT [66]. This therapeutic option is significant as daylight PDT is dependent on weather conditions and requires patient ability to go outside for light exposure. Other methods to reduce pain include a two-step irradiance treatment and using green light due to its decreased depth of tissue penetration $[67,68]$.

Recent investigations are evaluating combination therapies, comparing PDT protocols, and developing new photosensitizers. Microneedling as a pretreatment decreased ALA incubation time and decreased pain with similar efficacy to the conventional 1-h ALA incubation time method [69•]. Microneedling may assist with drug delivery as it may create microchannels to bypass the stratum corneum [69•]. Calcipotriol, a synthetic vitamin D derivative, may be used before PDT [70]. Patients undergoing PDT who were pretreated with calcipotriol were found to have fewer side effects and a higher clearance rate of AKs compared to those who received PDT only [71-73]. Calcipotriol pretreatment is thought to boost the amount of PpIX in the skin, thereby enhancing efficacy of field treatment [72]. Vignion-Dewalle et al. recently published a comprehensive in silico analysis of various PDT protocols using different lights to determine the regimen that offers the best complete response rate at 3 months [74.0]. The following top four protocols performed similarly: daylight PDT on a clear sunny day, daylight PDT on an overcast day, PDT with white LED lamp, and PDT with blue light $[74 \bullet \bullet]$. The development of new photosensitizers may be coupled with light therapy to form an alternative treatment. One example is photochemical internalization in which an amphiphilic photosensitizer along with a cytotoxic molecule or ribosomal-inactivation protein is given [75]. The cytotoxic compound is taken up into the cell and with light exposure, causes death by endosome rupture. Photochemical internalization is being studied in head and neck cancers but has not yet been reported for use in skin cancer [76].

\section{Needed to Study}

\section{SR-T100}

SR-T100 gel, not to be confused with the radiotherapy SRT100 , is a topical antiproliferative agent, with active ingredients solamargine, solasodine, and solasonine, thought to treat AKs through modulation of the tumor necrosis factor receptor signaling pathway [77]. A study in Taiwan reported 32\% complete clearance rate and $72 \%$ partial clearance rate for the group receiving SR-T100 gel compared with $12 \%$ complete clearance and $37 \%$ partial clearance rate for the control group [78]. The odds ratio for complete clearance was 2.14 and 4.36 for partial clearance [78]. The study gel was applied to an area that covered the AK and then covered by an occlusive dressing for $8 \mathrm{~h}$ daily for 16 weeks. In terms of safety, the rate of adverse events, 55.3\% (42/76) for SR-T100 and 51.4\% (19/ 37 ) for vehicle, and the rate of serious adverse events, $13.2 \%$ (10/76) for SR-T100 and 13.5 (5/37) for vehicle, were not statistically different. Serious adverse events were concluded to be unrelated to the study drug. Rates of erythema, burning/ stinging, and erosion were higher in the SR-T100 group compared to the vehicle group. While these initial results are promising, more studies are necessary to evaluate the field effects of this drug. SR-T100 is currently under investigation in a phase II clinical trial in the US (Table 1).

\section{2,4,6-Octatrienoic Acid}

2,4,6-octatrienoic acid is a parrodiene derivative that has been shown to activate peroxisome proliferator-activated receptor- $\gamma(\operatorname{PPAR} \gamma)$, reducing oxidative damage and inducing DNA repair enzymes thereby treating the field [79]. As far as the authors know, this is the only study that has used this agent to treat AKs. Patients in a phase IV study applied a topical cream containing 2,4,6-octatreinoic acid and urea twice daily 
for 2 months [80]. At the 3-month follow-up visit, $82.5 \%$ of patients achieved complete elimination of their AK lesions [80]. No side effects were reported although images provided in the article show common side effects such as erythema and crusting [80]. Patients were followed clinically and therefore lack histologic confirmation of lesion treatment. Further research with longer follow-up, periods, side effect reporting, and confirmation of $\mathrm{AK}$ treatment are necessary for this product.

\section{Nonthermal Atmospheric Pressure Plasma}

Nonthermal atmospheric pressure plasma, also known as cold atmospheric pressure plasma (CAP), is a new therapy being investigated for treatment of AKs. CAP demonstrated therapeutic potential in vitro and in animal models [81]. The mechanism of action is not fully understood but is thought to be related to ROS generation affecting cells undergoing DNA replication (i.e., cancer cells) [81]. This modality involves direct cutaneous contact of ionized gas without thermal damage to the skin [81]. One study using $120 \mathrm{~s}$ of CAP therapy twice weekly for seven applications on seven patients with extensive AKs showed promising potential as it resulted in clinical improvement and rejuvenating effects without adverse events or limitations on the maximum treatment area [82]. Another case series of five patients treated 17 lesions; 1 month after a single treatment lasting 1 to $2 \mathrm{~min}$, nine lesions completely resolved, three improved significantly, and five showed no major changes [83•]. Additionally, no side effects were noted [83•]. There is currently one study underway evaluating a CAP device for the treatment of various skin disorders, including AKs (Table 1). The preliminary results using $\mathrm{CAP}$ as a therapy for AKs are encouraging but more research is needed to study the mechanism, efficacy, safety, and optimal protocol for CAP.

\section{Lasers}

Cutaneous laser resurfacing may be used on an entire skin field to induce new collagen formation and remodeling. Fractional lasers target evenly spaced microthermal zones to minimize thermal damage [84]. Ablative lasers function at higher wavelengths to destroy the epidermis and dermis compared with nonablative lasers [35•].

Lasers are being investigated as monotherapy and as adjunctive applications in AK treatment [84]. One split-face study using ablative fractional laser (AFXL) therapy compared to no treatment for AKs found a significant reduction of AKs at 1 month; however, at the 3-month follow-up, reduction of AKs on either side of the face was similar due to spontaneous regression on the non-treated side [85]. In this study, the Ultrapulse $\mathrm{CO}_{2}$ laser ActiveFX handpiece (Lumenis) was used with the settings $70 \mathrm{~mJ}$ per pulse, power at $9 \mathrm{~W}$, and density of 4 [85]. In porcine skin, treatment with AFXL was found to induce more dermal deposition of ingenol mebutate [86]. Another study using AFXL in human 3D AK skin equivalents improved MAL uptake and improved PDT outcomes [87]. Fractional Q-switched 1064-nm Nd:YAG laser, a non-ablative laser typically used for tattoo and pigment treatment, is being studied for AK treatment [88]. After four sessions, complete clearance was observed in five out of six patients at the 3-month follow-up [88]. Evidence thus far appears to favor lasers as an adjunct to current therapies as they may facilitate delivery of topical agents, although the ideal monotherapy laser and settings have not been clearly defined yet.

Er:YAG ablative fractional laser-assisted MAL-PDT (AFL-PDT) as a combination therapy has shown positive results [89]. AFL-PDT was found to have an $84.8 \%$ response rate at 12 months and a $7.5 \%$ recurrence rate which was significantly better than the MAL-PDT only group with a $51.1 \%$ response rate and $22.1 \%$ recurrence rate [89]. Interestingly, no significant differences in pain were found across the treatment groups [89]. Another study found fractional $\mathrm{CO}_{2}$ followed by ALA-PDT to produce significantly higher clearance rates than ALA-PDT alone, $89.8 \%$ versus $71.2 \%$ at 12 weeks and better cosmesis as rated by the investigator and patients [90]. In terms of side effects, the laser group experienced slightly more intense pain and prolonged erythema [90]. Laser use for the treatment of AKs has shown favorable results but more studies are needed to determine efficacy and safety in a larger number of patients as well as determine how lasers best fit in the fielddirected AK treatment algorithm.

\section{Chemical Peels}

Chemical peels are another resurfacing technique, commonly used for cosmetic purposes, that is being studied for AK therapy. It is applied topically to cause chemical ablation of the skin, causing the superficial layers to slough off, inducing regeneration of the epidermis and dermis. One study compared one session of either ALA PDT or $35 \%$ trichloroacetic acid (TCA) peel [91]. Adverse events of TCA included persistent erythema, bacterial superinfection in one patient, and scarring in six patients [91]. Patients treated with ALA PDT demonstrated a complete clearance rate of $73.7 \%$ at the 12 month follow-up, compared with $48.8 \%$ in the TCA group [91]. Additionally, better Physician Global Assessment scores were noted with the MAL PDT group, with $54.5 \%$ of patients achieving completely clear or almost clear in target areas versus $11.8 \%$ in the TCA group [91]. Further studies with larger sample sizes, combination therapy with TCA, treatment confirmation with histology, and preventative studies may be needed to assess the role of chemical peels in $\mathrm{AK}$ management. 


\section{Conclusions}

Cutaneous field cancerization describes the process by which chronic UV exposure induces DNA damage and multifocal dysplastic cells. Genetic alterations, progressive invasion of atypical keratinocytes, and crusty, scaly growths may be observed. As a result, recent advances in field cancerization research have furthered understanding of the underlying pathophysiology of AKs and cSCCs. Examining cancer development through a field approach may lead to discoveries in other disease processes including basal cell carcinoma and melanoma. Furthermore, field-directed therapy is desirable for treating AKs as there are high recurrence rates of $\mathrm{CSCC}$ when therapy is lesion-directed. PDT, topical treatments, and lasers continue to be commonly employed therapies that are safe and efficacious. As current therapies for AKs are being optimized and new treatments are being developed, we expect efficacy of field therapy to improve. The combination of laser and topical treatments may enhance efficacy in the clinical setting. Comparing the genetic profile of pre- and post-AK treatment areas may reveal important biomarkers for disease progression or regression and allow for gene-targeted approaches.

Limitations of current research on field cancerization include the heterogenous nature of these lesions which pose a problem for classification methods, extrapolation of biopsy results to other lesions, and successful treatment of cSCC. Many clinicians use cryotherapy, a lesion-directed therapy, and may less often use or study field approaches. There is an unmet need for a better classification system for AKs that provides clinical predictability of lesion progression. Future studies should further elucidate the pathogenesis of field cancerization. Factors that differentiate the AKs that transform into cSCCs from those that remain benign or regress need further exploration. Finally, current and developing treatment options for AKs are abundant and studies are necessary to determine the safest and most effective therapies.

Field cancerization explains the continuum of photodamaged skin to cutaneous cSCC. Understanding this process will help guide future management such that patients may benefit the most.

\section{Compliance with Ethical Standards}

Conflict of Interest Alisen Huang, Evan Austin, Andrew Mamalis, and Jared Jagdeo received grants from Sun Pharmaceutical Industries Ltd. Dr. Jagdeo also received personal fees from Biofrontera.

Julie K. Nguyen declares no conflict of interest.

Human and Animal Rights and Informed Consent This article does not contain any studies with human or animal subjects performed by any of the authors.

Open Access This article is distributed under the terms of the Creative Commons Attribution 4.0 International License (http:// creativecommons.org/licenses/by/4.0/), which permits unrestricted use, distribution, and reproduction in any medium, provided you give appropriate credit to the original author(s) and the source, provide a link to the Creative Commons license, and indicate if changes were made.

\section{References}

Papers of particular interest, published recently, have been highlighted as:

- Of importance

•• Of major importance

1.• Lanoue J, Chen C, Goldenberg G. Actinic keratosis as a marker of field cancerization in excision specimens of cutaneous malignancies. Cutis. 2016;97(6):415-20. Provides evidence that field cancerization is present in basal cell carcinoma and malignant melanoma.

2. Christensen SR. Recent advances in field cancerization and management of multiple cutaneous squamous cell carcinomas. F1000Research. 2018;7. https://doi.org/10.12688/f1000research. 12837.1.

3. Slaughter DP, Southwick HW, Smejkal W. Field cancerization in oral stratified squamous epithelium; clinical implications of multicentric origin. Cancer. 1953;6(5):963-8.

4. Rogers HW, Weinstock MA, Feldman SR, Coldiron BM. Incidence estimate of nonmelanoma skin cancer (keratinocyte carcinomas) in the U.S. population, 2012. JAMA Dermatol. 2015;151(10):10816. https://doi.org/10.1001/jamadermatol.2015.1187.

5. Figueras Nart I, Cerio R, Dirschka T, Dreno B, Lear JT, Pellacani G, et al. Defining the actinic keratosis field: a literature review and discussion. J Eur Acad Dermatol Venereol. 2018;32(4):544-63. https://doi.org/10.1111/jdv.14652.

6. Lim HW, Collins SAB, Resneck JS Jr, Bolognia JL, Hodge JA, Rohrer TA, et al. The burden of skin disease in the United States. J Am Acad Dermatol. 2017;76(5):958-72.e2. https://doi.org/10. 1016/j.jaad.2016.12.043.

7. Yeung H, Baranowski ML, Swerlick RA, Chen SC, Hemingway J, Hughes DR, et al. Use and cost of actinic keratosis destruction in the Medicare Part B fee-for-service population, 2007 to 2015. JAMA Dermatol. 2018;154:1281-5. https://doi.org/10.1001/ jamadermatol.2018.3086.

8. Wenande E, Phothong W, Bay C, Karmisholt KE, Haedersdal M, Togsverd-Bo K. Efficacy and safety of daylight photodynamic therapy after tailored pretreatment with ablative fractional laser or microdermabrasion: a randomized, side-by-side, single-blind trial in patients with actinic keratosis and large-area field cancerization. Br J Dermatol. 2018;180:756-64. https://doi.org/10.1111/bjd. 17096.

9. Werner RN, Sammain A, Erdmann R, Hartmann V, Stockfleth E, Nast A. The natural history of actinic keratosis: a systematic review. $\mathrm{Br} \mathrm{J}$ Dermatol. 2013;169(3):502-18. https://doi.org/10.1111/bjd.12420.

10. Criscione VD, Weinstock MA, Naylor MF, Luque C, Eide MJ, Bingham SF. Actinic keratoses: natural history and risk of malignant transformation in the Veterans Affairs Topical Tretinoin Chemoprevention Trial. Cancer. 2009;115(11):2523-30. https:// doi.org/10.1002/cncr.24284.

11. Ashford BG, Clark J, Gupta R, Iyer NG, Yu B, Ranson M. Reviewing the genetic alterations in high-risk cutaneous squamous cell carcinoma: a search for prognostic markers and therapeutic targets. Head Neck. 2017;39(7):1462-9. https://doi.org/10.1002/hed.24765.

12. Fuchs A, Marmur E. The kinetics of skin cancer: progression of actinic keratosis to squamous cell carcinoma. Dermatol Surg. 2007;33(9): 1099-101. https://doi.org/10.1111/j.1524-4725.2007.33224.x. 
13. Narayanan DL, Saladi RN, Fox JL. Ultraviolet radiation and skin cancer. Int J Dermatol. 2010;49(9):978-86.

14. Matsumura Y, Ananthaswamy HN. Toxic effects of ultraviolet radiation on the skin. Toxicol Appl Pharmacol. 2004;195(3):298 308. https://doi.org/10.1016/j.taap.2003.08.019.

15. Roy S. Impact of UV radiation on genome stability and human health. Adv Exp Med Biol. 2017;996:207-19. https://doi.org/10. 1007/978-3-319-56017-5 17.

16. Schmitz L, Oster-Schmidt C, Stockfleth E. Nonmelanoma skin cancer - from actinic keratosis to cutaneous squamous cell carcinoma. J Dtsch Dermatol Ges. 2018;16(8):1002-13. https://doi.org/10. 1111/ddg.13614.

17. Olsen EA, Abernethy ML, Kulp-Shorten C, Callen JP, Glazer SD, Huntley A, et al. A double-blind, vehicle-controlled study evaluating masoprocol cream in the treatment of actinic keratoses on the head and neck. J Am Acad Dermatol. 1991;24(5 Pt 1):738-43.

18. Rowert-Huber J, Patel MJ, Forschner T, Ulrich C, Eberle J, Kerl H, et al. Actinic keratosis is an early in situ squamous cell carcinoma: a proposal for reclassification. Br J Dermatol. 2007;156(Suppl 3):812. https://doi.org/10.1111/j.1365-2133.2007.07860.x.

19.• Fernandez-Figueras MT, Carrato C, Saenz X, Puig L, Musulen E, Ferrandiz C, et al. Actinic keratosis with atypical basal cells (AK I) is the most common lesion associated with invasive squamous cell carcinoma of the skin. J Eur Acad Dermatol Venereol. 2015;29(5): 991-7. https://doi.org/10.1111/jdv.12848 Indicates that AKs do not necessarily progress in a stepwise manner as previously thought.

20. Campione E, Ventura A, Diluvio L, Mazzeo M, Mazzilli S, Garofalo V, et al. Current developments in pharmacotherapy for actinic keratosis. Expert Opin Pharmacother. 2018;19:1-12. https://doi.org/10.1080/14656566.2018.1523896.

21. Braakhuis BJ, Tabor MP, Kummer JA, Leemans CR, Brakenhoff RH. A genetic explanation of Slaughter's concept of field cancerization: evidence and clinical implications. Cancer Res. 2003;63(8):1727-30.

22. Lee CS, Bhaduri A, Mah A, Johnson WL, Ungewickell A, Aros CJ, et al. Recurrent point mutations in the kinetochore gene KNSTRN in cutaneous squamous cell carcinoma. Nat Genet. 2014;46(10): 1060-2. https://doi.org/10.1038/ng.3091.

23. Houh YK, Kim KE, Park HJ, Cho D. Roles of erythroid differentiation regulator 1 (Erdr1) on inflammatory skin diseases. Int J Mol Sci. 2016;17(12):2059. https://doi.org/10.3390/ijms17122059.

24. Dooley TP, Reddy SP, Wilborn TW, Davis RL. Biomarkers of human cutaneous squamous cell carcinoma from tissues and cell lines identified by DNA microarrays and qRT-PCR. Biochem Biophys Res Commun. 2003;306(4):1026-36.

25. Hameetman L, Commandeur S, Bavinck JN, Wisgerhof HC, de Gruijl FR, Willemze R, et al. Molecular profiling of cutaneous squamous cell carcinomas and actinic keratoses from organ transplant recipients. BMC Cancer. 2013;13:58. https://doi.org/10.1186/ 1471-2407-13-58.

26. Levine DE, Karia PS, Schmults CD. Outcomes of patients with multiple cutaneous squamous cell carcinomas: a 10-year singleinstitution cohort study. JAMA Dermatol. 2015;151(11):1220-5. https://doi.org/10.1001/jamadermatol.2015.1702.

27. Schmitz L, Gambichler T, Gupta G, Stucker M, Stockfleth E, Szeimies RM, et al. Actinic keratoses show variable histological basal growth patterns - a proposed classification adjustment. J Eur Acad Dermatol Venereol. 2018;32(5):745-51. https://doi.org/10. $1111 / j d v .14512$

28. Cerio R, Dirschka T, Dreno B, Figueras Nart I, Lear JT, Pellacani G, et al. Actinic keratosis, a chronic, progressive disease: understanding clinical gaps to optimise patient management. Acta Derm Venereol. 2017;97(8):997-8. https://doi.org/10.2340/000155552692.
29. Dirschka T, Pellacani G, Micali G, Malvehy J, Stratigos AJ, Casari A, et al. A proposed scoring system for assessing the severity of actinic keratosis on the head: actinic keratosis area and severity index. J Eur Acad Dermatol Venereol. 2017;31(8):1295-302. https://doi.org/10.1111/jdv.14267.

30. Dreno B, Cerio R, Dirschka T, Nart IF, Lear JT, Peris K, et al. A novel actinic keratosis field assessment scale for grading actinic keratosis disease severity. Acta Derm Venereol. 2017;97(9):110813. https://doi.org/10.2340/00015555-2710.

31. Schmitz L, Stucker M, Gambichler T, Stockfleth E, Dirschka T. Histological intralesional heterogeneity of actinic keratoses relates to field cancerization. J Dtsch Dermatol Ges. 2018;16(10):1211-7. https://doi.org/10.1111/ddg.13658.

32. Chen AC, Martin AJ, Choy B, Fernandez-Penas P, Dalziell RA, McKenzie CA, et al. A phase 3 randomized trial of nicotinamide for skin-cancer chemoprevention. N Engl J Med. 2015;373(17): 1618-26. https://doi.org/10.1056/NEJMoa1506197.

33. Jetter N, Chandan N, Wang S, Tsoukas M. Field cancerization therapies for management of actinic keratosis: a narrative review. Am J Clin Dermatol. 2018;19(4):543-57. https://doi.org/10.1007/ s40257-018-0348-7.

34. Stockfleth E. The importance of treating the field in actinic keratosis. J Eur Acad Dermatol Venereol. 2017;31(Suppl 2):8-11. https:// doi.org/10.1111/jdv.14092.

35. Dong J, Goldenberg G. Energy-based devices for actinic keratosis field therapy. Cutis. 2018;101(5):355-60 This article reviews laser and light therapies for field-directed treatment of AKs.

36. Jagdeo JR, Brody NI, Spandau DF, Travers JB. Important implications and new uses of ablative lasers in dermatology: fractional carbon dioxide laser prevention of skin cancer. Dermatol Surg. 2015;41(3):387-9. https://doi.org/10.1097/dss. 0000000000000308.

37. Philipp-Dormston WG. Field cancerization: from molecular basis to selective field-directed management of actinic keratosis. Curr Probl Dermatol. 2015;46:115-21. https://doi.org/10.1159/ 000366547.

38. Uhlenhake EE. Optimal treatment of actinic keratoses. Clin Interv Aging. 2013;8:29-35. https://doi.org/10.2147/CIA.S31930.

39. Zyclara (imiquimod) [package insert]. $3 \mathrm{M}$ Health Care Limited: Loughborough; 2011.

40. Aldara (imiquimod) [package insert], 3M Health Care Limited: Loughborough; 2010.

41. Stockfleth E, Sibbring GC, Alarcon I. New topical treatment options for actinic keratosis: a systematic review. Acta Derm Venereol. 2016;96(1):17-22. https://doi.org/10.2340/00015555-2167.

42. Kishi P, Price CJ. Life-threatening reaction with topical 5-fluorouracil. Drug Saf Case Rep. 2018;5(1):4. https://doi.org/10.1007/ s40800-017-0068-6.

43. Bhatta AK, Wang P, Keyal U, Zhao Z, Ji J, Zhu L, et al. Therapeutic effect of Imiquimod enhanced ALA-PDT on cutaneous squamous cell carcinoma. Photodiagn Photodyn Ther. 2018;23:273-80. https://doi.org/10.1016/j.pdpdt.2018.07.010.

44. Chughtai K, Gupta R, Upadhaya S, Al Hadidi S. Topical 5fluorouracil associated skin reaction. Oxf Med Case Reports. 2017;2017(8):omx043. https://doi.org/10.1093/omcr/omx043.

45. Cunningham TJ, Tabacchi M, Eliane JP, Tuchayi SM, Manivasagam S, Mirzaalian H, et al. Randomized trial of calcipotriol combined with 5-fluorouracil for skin cancer precursor immunotherapy. J Clin Invest. 2017;127(1):106-16. https://oi. org/10.1172/jci89820.

46. Del Rosso J, Swanson N, Berman B, Martin GM, Lin T, Rosen T. Imiquimod $2.5 \%$ and $3.75 \%$ cream for the treatment of photodamage: a meta-analysis of efficacy and tolerability in 969 randomized patients. J Clin Aesthet Dermatol. 2018;11(9):28-31.

47. Ohgari Y, Nakayasu Y, Kitajima S, Sawamoto M, Mori H, Shimokawa $\mathrm{O}$, et al. Mechanisms involved in delta- 
aminolevulinic acid (ALA)-induced photosensitivity of tumor cells: relation of ferrochelatase and uptake of ALA to the accumulation of protoporphyrin. Biochem Pharmacol. 2005;71(1-2):42-9. https://doi.org/10.1016/j.bcp.2005.10.019.

48. Maytin EV, Kaw U, Ilyas M, Mack JA, Hu B. Blue light versus red light for photodynamic therapy of basal cell carcinoma in patients with Gorlin syndrome: a bilaterally controlled comparison study. Photodiagn Photodyn Ther. 2018;22:7-13. https://doi.org/10.1016/ j.pdpdt.2018.02.009.

49. Li Y, Zhang J, Xu Y, Han Y, Jiang B, Huang L, et al. The histopathological investigation of red and blue light emitting diode on treating skin wounds in Japanese big-ear white rabbit. PLoS One. 2016;11(6):e0157898-e. https://doi.org/10.1371/journal.pone. 0157898

50. Petersen B, Wiegell SR, Wulf HC. Light protection of the skin after photodynamic therapy reduces inflammation: an unblinded randomized controlled study. Br J Dermatol. 2014;171(1):175-8. https://doi.org/10.1111/bjd.12882.

51. Gold MH, Kauvar AN, Taub AF, Geronemus RG, Ritvo EC, Goldman MP et al. The use of photodynamic therapy in dermatology: results of a consensus conference. J Drugs Dermatol. 2006;5(2).

52.• Joly F, Deret S, Gamboa B, Menigot C, Fogel P, Mounier C et al. Photodynamic therapy corrects abnormal cancer-associated gene expression observed in actinic keratosis lesions and induces a remodeling effect in photodamaged skin. J Dermatol Sci. 2018. https://doi.org/10.1016/j.jdermsci.2018.05.002. Provides evidence of transcriptional remodeling of AK lesions after MAL-PDT.

53. Reinhold U, Dirschka T, Ostendorf R, Aschoff R, Berking C, Philipp-Dormston WG, et al. A randomized, double-blind, phase III, multicentre study to evaluate the safety and efficacy of BF-200 ALA (Ameluz((R)) ) vs. placebo in the field-directed treatment of mild-to-moderate actinic keratosis with photodynamic therapy (PDT) when using the BF-RhodoLED((R)) lamp. Br J Dermatol. 2016;175(4):696-705. https://doi.org/10.1111/bjd.14498.

54.• Willey A, Anderson RR, Sakamoto FH. Temperature-modulated photodynamic therapy for the treatment of actinic keratosis on the extremities: a one-year follow-up study. Dermatol Surg. 2015;41(11):1290-5. https://doi.org/10.1097/dss. 000000000000512 A pivotal study for thermal PDT.

55. Koo E, Austin E, Mamalis A, Jagdeo J. Thermal ultra short photodynamic therapy: heating fibroblasts during sub-30-minute incubation of 5-aminolevulinic acid increases photodynamic therapyinduced cell death. Dermatol Surg. 2018;44(4):528-33. https:// doi.org/10.1097/dss.0000000000001341.

56. Austin E, Koo E, Jagdeo J. Thermal photodynamic therapy increases apoptosis and reactive oxygen species generation in cutaneous and mucosal squamous cell carcinoma cells. Sci Rep. 2018;8(1):12599. https://doi.org/10.1038/s41598-018-30908-6.

57. Koo E, Austin E, Mamalis A, Jagdeo J. Efficacy of ultra short sub30 minute incubation of 5-aminolevulinic acid photodynamic therapy in vitro. Lasers Surg Med. 2017;49(6):592-8. https://doi.org/ 10.1002/lsm.22648.

58.• Mamalis A, Koo E, Sckisel GD, Siegel DM, Jagdeo J. Temperature-dependent impact of thermal aminolaevulinic acid photodynamic therapy on apoptosis and reactive oxygen species generation in human dermal fibroblasts. Br J Dermatol. 2016;175(3):512-9. https://doi.org/10.1111/bjd.14509 This study provides evidence of increased apoptosis with thermal PDT.

59. Demay SDJ, Sharma K, Sapra S, Sapra R, Sapra P. Daylightmediated photodynamic therapy with methyl aminolevulinate in actinic keratosis treatment. J Cutan Med Surg. 2018;22(3):26772. https://doi.org/10.1177/1203475417752367.
60. Fargnoli MC, Piccioni A, Neri L, Tambone S, Pellegrini C, Peris K. Long-term efficacy and safety of daylight photodynamic therapy with methyl amninolevulinate for actinic keratosis of the face and scalp. Eur J Dermatol. 2017;27(1):89-91. https://doi.org/10.1684/ ejd.2016.2882.

61. Lacour JP, Ulrich C, Gilaberte Y, Von Felbert V, Basset-Seguin N, Dreno B, et al. Daylight photodynamic therapy with methyl aminolevulinate cream is effective and nearly painless in treating actinic keratoses: a randomised, investigator-blinded, controlled, phase III study throughout Europe. J Eur Acad Dermatol Venereol. 2015;29(12):2342-8. https://doi.org/10.1111/jdv.13228.

62. Rubel DM, Spelman L, Murrell DF, See JA, Hewitt D, Foley P, et al. Daylight photodynamic therapy with methyl aminolevulinate cream as a convenient, similarly effective, nearly painless alternative to conventional photodynamic therapy in actinic keratosis treatment: a randomized controlled trial. Br J Dermatol. 2014;171(5): 1164-71. https://doi.org/10.1111/bjd.13138.

63. Sotiriou E, Evangelou G, Papadavid E, Apalla Z, Vrani F, Vakirlis $\mathrm{E}$, et al. Conventional vs. daylight photodynamic therapy for patients with actinic keratosis on face and scalp: 12-month follow-up results of a randomized, intra-individual comparative analysis. J tEur Acad Dermatol Venereol. 2018;32(4):595-600. https://doi. org/10.1111/jdv.14613.

64. Wiegell SR, Haedersdal M, Philipsen PA, Eriksen P, Enk CD, Wulf HC. Continuous activation of PpIX by daylight is as effective as and less painful than conventional photodynamic therapy for actinic keratoses; a randomized, controlled, single-blinded study. Br J Dermatol. 2008;158(4):740-6. https://doi.org/10.1111/j.13652133.2008.08450.x.

65. Fargnoli MC, Piccioni A, Neri L, Tambone S, Pellegrini C, Peris K. Conventional vs. daylight methyl aminolevulinate photodynamic therapy for actinic keratosis of the face and scalp: an intra-patient, prospective, comparison study in Italy. J Eur Acad Dermatol Venereol. 2015;29(10):1926-32. https://doi.org/10.1111/jdv.13076.

66. Marra K, LaRochelle EP, Chapman MS, Hoopes PJ, Lukovits K, Maytin EV, et al. Comparison of blue and white lamp light with sunlight for daylight-mediated, 5-ALA photodynamic therapy, in vivo. Photochem Photobiol. 2018;94(5):1049-57. https://doi. org/10.1111/php. 12923 .

67. Paragh G, Zeitouni NC. Two-step irradiance treatment can achieve excellent pain control during red light 5 -aminolevulinic acid photodynamic therapy for actinic Keratoses. Photomed Laser Surg. 2018;36(3):174-6. https://doi.org/10.1089/pho.2017.4351.

68. Osiecka BJ, Nockowski P, Szepietowski JC. Treatment of actinic keratosis with photodynamic therapy using red or green light: a comparative study. Acta Derm Venereol. 2018;98(7):689-93. https://doi.org/10.2340/00015555-2931.

69. Petukhova TA, Hassoun LA, Foolad N, Barath M, Sivamani RK. Effect of expedited microneedle-assisted photodynamic therapy for field treatment of actinic keratoses: a randomized clinical trial. JAMA Dermatol. 2017;153(7):637-43. https://doi.org/10.1001/ jamadermatol.2017.0849 This study used microneedling as a method to increase delivery of photosensitizers.

70. Bay C, Lerche CM, Togsverd-Bo K, Wulf HC, Haedersdal M. Calcipotriol pretreatment enhances methyl aminolevulinateinduced protoporphyrin IX: an in vivo study in hairless mice. Photodermatol Photoimmunol Photomed. 2015;31(1):57-60. https://doi.org/10.1111/phpp.12150.

71. Galimberti GN. Daylight photodynamic therapy versus 5fluorouracil for the treatment of actinic keratosis: a case series. Dermatol Ther. 2018;8(1):137-41. https://doi.org/10.1007/ s13555-017-0219-9.

72. Torezan L, Grinblat B, Haedersdal M, Valente N, Festa-Neto C, Szeimies RM. A randomized split-scalp study comparing calcipotriol-assisted methyl aminolaevulinate photodynamic therapy (MAL-PDT) with conventional MAL-PDT for the treatment of 
actinic keratosis. Br J Dermatol. 2018;179(4):829-35. https://doi. org/10.1111/bjd.16473.

73. Seo JW, Song KH. Topical calcipotriol before ablative fractional laser-assisted photodynamic therapy enhances treatment outcomes for actinic keratosis in Fitzpatrick grades III-V skin: a prospective randomized clinical trial. J Am Acad Dermatol. 2018;78(4):795-7. https://doi.org/10.1016/j.jaad.2017.11.027.

74.• Vignion-Dewalle AS, Baert G, Thecua E, Lecomte F, Vicentini C, Abi-Rached H, et al. Comparison of 10 efficient protocols for photodynamic therapy of actinic keratosis: how relevant are effective light dose and local damage in predicting the complete response rate at 3 months? Lasers Surg Med. 2018;50(5):576-89. https://doi. org/10.1002/1sm.22827 This article compares various PDT protocols and is important for treatment optimization.

75. Abrahamse H, Hamblin MR. New photosensitizers for photodynamic therapy. Biochem J. 2016;473(4):347-64.

76. Jerjes W, Upile T, Radhi H, Hopper C. Photodynamic therapy vs photochemical internalization: the surgical margin. Head Neck Oncol. 2011;3:53. https://doi.org/10.1186/1758-3284-3-53.

77. Wu CH, Liang CH, Shiu LY, Chang LC, Lin TS, Lan CC, et al. Solanum incanum extract (SR-T100) induces human cutaneous squamous cell carcinoma apoptosis through modulating tumor necrosis factor receptor signaling pathway. J Dermatol Sci. 2011;63(2):83-92. https://doi.org/10.1016/j.jdermsci.2011.04.003.

78. Yang CC, Wong TW, Lee CH, Hong CH, Chang CH, Lai FJ, et al. Efficacy and safety of topical SR-T100 gel in treating actinic keratosis in Taiwan: a phase III randomized double-blind vehicle-controlled parallel trial. J Dermatol Sci. 2018;90(3):295-302. https:// doi.org/10.1016/j.jdermsci.2018.02.015.

79. Flori E, Mastrofrancesco A, Kovacs D, Ramot Y, Briganti S, Bellei B, et al. 2,4,6-Octatrienoic acid is a novel promoter of melanogenesis and antioxidant defence in normal human melanocytes via PPAR-gamma activation. Pigment Cell Melanoma Res. 2011;24(4):618-30. https://doi.org/10.1111/j.1755-148X.2011. 00887.x.

80. De Padova MP, Marzani B, Pinto D, Rinaldi F. A single-arm, openlabel, phase IV study to evaluate the efficacy of a topical formulation for hyperkeratotic actinic keratosis lesions. Dermatol Ther. 2018;8(3):455-62. https://doi.org/10.1007/s13555-018-0252-3.

81. Gan L, Zhang S, Poorun D, Liu D, Lu X, He M, et al. Medical applications of nonthermal atmospheric pressure plasma in dermatology. J Dtsch Dermatol Ges. 2018;16(1):7-13. https://doi.org/10. 1111/ddg.13373.

82. Wirtz M, Stoffels I, Dissemond J, Schadendorf D, Roesch A. Actinic keratoses treated with cold atmospheric plasma. J Eur Acad Dermatol Venereol. 2018;32(1):e37-e9. https://doi.org/10. $1111 /$ jdv.14465.
83. Friedman PC, Miller V, Fridman G, Lin A, Fridman A. Successful treatment of actinic keratoses using nonthermal atmospheric pressure plasma: a case series. J Am Acad Dermatol. 2017;76(2):349 50. https://doi.org/10.1016/j.jaad.2016.09.004 An important study for a new potential treatment modality of AKs.

84. Alexiades-Armenakas MR, Dover JS, Arndt KA. The spectrum of laser skin resurfacing: nonablative, fractional, and ablative laser resurfacing. J Am Acad Dermatol. 2008;58(5):719-37; quiz 3840. https://doi.org/10.1016/j.jaad.2008.01.003.

85. Gan SD, Hsu SH, Chuang G, Konnikov N, Liang CA. Ablative fractional laser therapy for the treatment of actinic keratosis: a split-face study. J Am Acad Dermatol. 2016;74(2):387-9. https:// doi.org/10.1016/j.jaad.2015.08.035.

86. Erlendsson AM, Taudorf EH, Eriksson AH, Haak CS, Zibert JR, Paasch U, et al. Ablative fractional laser alters biodistribution of ingenol mebutate in the skin. Arch Dermatol Res. 2015;307(6): 515-22. https://doi.org/10.1007/s00403-015-1561-3.

87. Huth S, Marquardt Y, Amann PM, Leverkus M, Huth L, Baron JM, et al. Ablative non-sequential fractional ultrapulsed $\mathrm{CO} 2$ laser pretreatment improves conventional photodynamic therapy with meth$\mathrm{yl}$ aminolevulinate in a novel human in vitro $3 \mathrm{D}$ actinic keratosis skin model. Exp Dermatol. 2016;25(12):997-9. https://doi.org/10. 1111/exd.13068.

88. Gold MH, Sensing W, Biron J. Fractional Q-switched 1,064-nm laser for the treatment of photoaged-photodamaged skin. J Cosmet Laser Ther. 2014;16(2):69-76. https://doi.org/10.3109/ 14764172.2013.864197.

89. Choi SH, Kim KH, Song KH. Efficacy of ablative fractional laserassisted photodynamic therapy with short-incubation time for the treatment of facial and scalp actinic keratosis: 12-month follow-up results of a randomized, prospective, comparative trial. J Eur Acad Dermatol Venereol. 2015;29(8):1598-605. https://doi.org/10.1111/ jdv. 12953.

90. Alexiades M. Randomized, controlled trial of fractional carbon dioxide laser resurfacing followed by ultrashort incubation aminolevulinic acid blue light photodynamic therapy for actinic keratosis. Dermatol Surg. 2017;43(8):1053-64. https://doi.org/10. 1097/dss.0000000000001117.

91. Holzer G, Pinkowicz A, Radakovic S, Schmidt JB, Tanew A. Randomized controlled trial comparing 35\% trichloroacetic acid peel and 5-aminolaevulinic acid photodynamic therapy for treating multiple actinic keratosis. Br J Dermatol. 2017;176(5):1155-61. https://doi.org/10.1111/bjd.15272.

Publisher's Note Springer Nature remains neutral with regard to jurisdictional claims in published maps and institutional affiliations. 